Article

\title{
Developing a Cooperative Model Converging Both Convention and Medical Tourism Stakeholders: Based on Deutsch's Cooperation Theory
}

\author{
Deoksoo Ahn ${ }^{1}$, Jun Heo ${ }^{2}$ and Chulwon Kim ${ }^{3, * \mathbb{D}}$ \\ 1 Korea Tourism Organization, Seoul 04521, Korea; ads@knto.or.kr \\ 2 Global MICE Major, Dongduk Women's University, Seoul 02748, Korea; hjun4mice@dongduk.ac.kr \\ 3 College of Hotel and Tourism Management, Kyung Hee University, Seoul 02447, Korea \\ * Correspondence: kimcw@khu.ac.kr
}

Received: 9 July 2020; Accepted: 13 August 2020; Published: 17 August 2020

check for updates

\begin{abstract}
This study aimed to develop the cooperative model converging stakeholders in both the convention and medical tourism sectors. It was to derive factors representing collaboration toward common goals and values recognized by both sectors from the stakeholders' perspectives through qualitative research methods. The study applied Deutsch's cooperation theory, which states that cooperation is directed toward group goals and selected due to rational decision-making. For a systematic and reliable analysis of the collected data, Spradley's 12-stage technique was modified into seven stages, such as the domain, taxonomic, and component analyses, to fit this study's context. The convention-medical tourism cooperation model was aptly named "CON-MED" cooperation model.
\end{abstract}

Keywords: cooperation; convention industry; medical tourism; stakeholder

\section{Introduction}

Hospitality and tourism are mostly assembly processes, just like many modern industries [1]. Vertical integration is not a hallmark of most hospitality and tourism operations. Likewise, horizontal integration is relatively rare. The widespread and fragmented nature of hospitality and tourism has long been recognized. How to overcome the problems caused by fragmentation has also been pursued for a long time [1-3]. Hospitality and tourism have recently experienced the emerging convergence era with the value-based economy and collaborative economy [4]. The new form of hospitality and tourism has become a policy framework that emphasizes cooperation between diverse industries, such as entertainment, healthcare, MICE (meetings, incentive travel, conventions, and exhibitions), sports, ICT (information communication technology), and manufacturing.

Convergence has linked with collaboration among various stakeholders to create a high value-added effect. Recently, studies addressing collaboration or strategic alliances among enterprises in different sectors have been rapidly increasing. Along with changes in social and policy environments, the cooperation trend has diffused in the tourism industry. Specifically, cooperation has emerged as a policy measure to create demand in the supply system. Industrial cooperation is a way of creating new markets by combining independent technologies and services in different existing sectors. Therefore, academic consideration of cooperation among stakeholders is most necessary. However, despite the increasing interest in research on cooperation among various tourism sectors [5-7], studies addressing specific cases or empirical results are insufficient [8].

Airbnb customer experience as evidence of convergence across three countries [9], the role of CSR (corporate social responsibility) in the organizational identity of hospitality companies [10], 
collaboration between the film and tourism industries [11], organic, incremental, and induced paths to sustainable mass tourism convergence [12], smart tourism as the convergence of information technologies [13], and collaborative commerce in tourism [14] are some of the existing literature.

In recent decades both convention and medical tourism sectors in the hospitality and tourism industry have become popular and rapidly evolving tourism trends [15-17].

The convention industry generates a significant economic impact and is rapidly diversifying. The convention industry is the most lucrative segment in the hospitality and tourism fields. Many different stakeholders are concerned with the convention industry because it is an essential factor in promoting inbound tourism in most countries. Regarding medical tourism, for which the areas of academic studies have been expanding recently, research has been mainly conducted on individual medical tourists from the viewpoint of behavioralism to find selection attributes and participation intentions [18]. Wernz et al. [19] explored service convergence and service integration in medical tourism. However, previous studies on cooperation between the convention industry and medical tourism stakeholders are quite scarce.

In order to fill the gap, the purpose of this study is to develop a cooperative model among stakeholders in both the convention industry and medical tourism sectors. It aims to derive cooperative factors reflecting common goals and values recognized by both sectors. The specific purposes of this study are as follows.

The study aims to draw the essential meanings of collaboration recognized by experts in both sectors. This goal is achieved by applying elements in cooperation processes. It would derive factors for cooperation among both sectors' stakeholders, including the categorization of the derived factors for cooperation, development of a networked cooperation model, and suggestion of policy and practical implications for intensifying partnerships among both sectors' stakeholders.

\section{Theoretical Background}

\subsection{Stakeholders}

The Stanford Research Institute began to use the term "stakeholder" in 1963, defining groups that are indispensable for organizations' operation. "Stakeholder" refers to significant groups that act for the continuing existence and maintenance of enterprises' functions and management activities in a limited sense. It also includes individuals or groups that affect or are affected by enterprises' functions and management activities in a broad sense [20].

Freeman [21] and Gray [22] expanded the range of stakeholders to individuals or groups that influence the purpose and activities of organizations and are in turn affected by the results, that is, individuals or groups affected by or have interest in a particular organization or action [23]. Accommodating Freeman's [21] viewpoint, Davis et al. [24] defined corporate stakeholders as those who have the right to participate in decision making for management activities.

Regarding tourism, the United Nations World Tourism Organization (UNWTO) defined stakeholders as experts and public institutions related to tourist agencies and mass media that are firmly related to tourism [25].

\subsection{Convention and Medical Tourism Stakeholders}

Convention-related stakeholders are diversely defined and classified. Jamal and Getz [2] identified convention industry-related stakeholders as local governments, public institutions, the Chamber of Commerce and Industry, the Convention and Visitors Bureau Convention (CVB), local tourism authorities, and resident and social organizations. The medical tourism stakeholders include the central government that establishes medical tourism policies, medical tourism businesses, and related organizations. Related central government departments include the respective ministries of Health Welfare, Culture, Sports and Tourism, Strategy and Finance, Justice, Foreign Affairs and Trade, Labor, and Education. The organizations include the Korea Tourism Organization and the Korea Health 
Industry Development Institute that have come to play some roles and the growth of the medical tourism industry in Korea. Panasiuk et al. [26] identified the internal network of travel organizers, specialized sale agencies, human capital companies, firms promoting knowledge, recipients of services, accommodation providers, and insurance agencies.

\subsection{Deutsch's Cooperation Theory}

Deutsch [27] presented a cooperation selection theory applied with the utility theory [28] or the aspiration-level theory [29]. Deutsch's [30] cooperation theory also indicates that individuals or people cooperate toward group goals connected to individual goals and select cooperation due to rational and cognitive decision-making. Although most studies related to this model have been conducted on interpersonal relationships, the cooperation theory is also suitable for studies on the relationships between departments in an organization and other groups [31].

Deutsch's cooperation theory could apply in several situations. One is when the appropriateness of the moment of cooperation can be checked, based on prospective cooperators' desirability and reciprocity in the stage before cooperation to minimize conflicts in the process of cooperation. Another is when it is possible to concretely observe what cooperation and competition processes are performed by the factors for cooperation in achieving common goals [32]. A third situation is when the intensities of cooperation among individuals, enterprises, and industries are established [33].

Deutsch pointed out that groups also perceive competition and cooperation based on goal dependence, leading to social interaction differences. The contents of cooperation and competition processes in Deutsch's cooperation theory are shown in Table 1.

Table 1. Cooperation and competition processes in Deutsch's cooperation theory.

\begin{tabular}{|c|c|c|}
\hline Domain & Cooperation Process & Competition Process \\
\hline Communication & $\begin{array}{l}\text { Facilitate communication. } \\
\text { Provide accurate and frank communication. } \\
\text { Provide mutually beneficial communication. }\end{array}$ & $\begin{array}{l}\text { Provide the wrong information. } \\
\text { Mislead others and avoid communication. } \\
\text { Spy on the information. }\end{array}$ \\
\hline Perception & $\begin{array}{l}\text { Be sensitive to similarities and common } \\
\text { understandings. } \\
\text { Accommodate others' viewpoints. }\end{array}$ & $\begin{array}{l}\text { Be sensitive to differences and threats. } \\
\text { Stimulate opposing sentiments. } \\
\text { Avoid others' viewpoints. }\end{array}$ \\
\hline Attitudes toward each other & $\begin{array}{l}\text { Demonstrate friendly attitudes. } \\
\text { Give cooperative responses. } \\
\text { Establish mutual trust. }\end{array}$ & $\begin{array}{l}\text { Show doubt and hostility. } \\
\text { Increase the intention to exploit others. } \\
\text { Exhibit mutual distrust. }\end{array}$ \\
\hline Work orientation & $\begin{array}{l}\text { Improve the division of labor and productivity. } \\
\text { Share and adjust resources. } \\
\text { Settle conflicts in a constructive manner. } \\
\text { Adjust to each other's interests. } \\
\text { Reduce the range of conflicting relationships. } \\
\text { Improve each other's power and resources. }\end{array}$ & $\begin{array}{l}\text { Hinder the division of labor. } \\
\text { Hinder resource sharing. } \\
\text { Hinder activity adjustment. } \\
\text { Stimulate unilateral settlements of conflicts. } \\
\text { Increase the power of one party. } \\
\text { Use coercion, threats, and deception. }\end{array}$ \\
\hline
\end{tabular}

Source: Deutsch [27].

\section{Study and Data Analysis Methods}

\subsection{Study Method}

Deutsch's cooperation theory was applied to achieve this study's purposes, figuring out factors for cooperation between convention and medical tourism stakeholders, and developing a cooperation model. In this regard, several qualitative methods were also used. With the focus on Deutsch's cooperation theory, factors for cooperation between the convention industry and medical tourism sectors were derived through in-depth interviews and questionnaire surveys conducted with sector experts. Spradley's analysis technique [34] was used for categorizing convention-medical tourism cooperation factors. By applying Chen's [35] program logic theory, a convention-medical tourism cooperation model was developed. 


\subsection{Utilization of Spradley's Analysis Technique}

In his book Participant Observation, Spradley presented a 12-stage, qualitative analysis for participatory observation. The 12 stages were modified and newly constructed into 7 stages to fit this study, which reflected methodological differences in data collection. These seven stages included selecting the subjects of analysis, recording expert survey results, domain analysis, taxonomic analysis, component analysis, system organization, and content preparation.

\section{Derivation of Cooperation Factors of Convention-Medical Tourism}

\subsection{Overview of In-Depth Expert Interviews}

The in-depth interviews with experts were conducted first to explore the validity of Deutsch's cooperation theory and the possibility of deriving the four domains of the cooperation theory (communication, perception, attitudes toward each other, and work orientation), but also other domains of cooperation. The interviews were carried out from January 4 to 18, 2018, with four experts in the convention and medical tourism sectors. Table 2 shows the interview questions.

Table 2. The in-depth interview questions.

\begin{tabular}{cc}
\hline No. & Questions \\
\hline 1 & How do you understand Deutsch's cooperation theory? \\
\hline 2 & Do you understand the four domains (communication, perception, attitudes toward each \\
other, and work orientation) in Deutsch's cooperation theory?
\end{tabular}

The interview results indicate that most experts' overall understanding of Deutsch's cooperation theory was high. Based on their broad understanding of the four domains of cooperation, these could be perceived as necessary for cooperation among the convention industry and medical tourism stakeholders.

\subsection{Overview of the First Expert Questionnaire Survey}

The study prepared an initial list of survey subjects, consisting of experts with higher education and long-term practical experience in the convention industry and medical tourism. Thirty experts were selected from convention bureaus, convention centers, local tourism organizations, the Korea Tourism Organization, the PCO, professors, doctors, persons involved in medical institutions, and experts in other related areas from the Repubic of Korea. Survey subjects were stakeholders among both the convention industry and medical tourism sectors in Korea. Tables 3 and 4 show the expert survey panels.

Table 3. Institutional affiliations or occupations of the expert survey panels (unit: person).

\begin{tabular}{cccccccc}
\hline $\begin{array}{c}\text { Convention } \\
\text { Bureau }\end{array}$ & $\begin{array}{c}\text { Convention } \\
\text { Center }\end{array}$ & $\begin{array}{c}\text { Local Tourism } \\
\text { Organization }\end{array}$ & $\begin{array}{c}\text { Korea Tourism } \\
\text { Organization }\end{array}$ & PCO & Professor & Doctor & $\begin{array}{c}\text { Persons in } \\
\text { Medical } \\
\text { Institutions }\end{array}$ \\
\hline 3 & 3 & 3 & 4 & 1 & 3 & 5 & 5 \\
\hline
\end{tabular}

Table 4. General status of the expert survey panels (unit: person).

\begin{tabular}{cccccccccccccc}
\hline \multicolumn{2}{c}{ Gender } & \multicolumn{3}{c}{ Age } & \multicolumn{4}{c}{ Service Tenure } & \multicolumn{3}{c}{ Academic Background } \\
\hline Male & Female & 30s & 40s & 50s & 60s & $\begin{array}{c}\mathbf{1 0 - 1 4} \\
\text { Years }\end{array}$ & $\begin{array}{c}\mathbf{1 5 - 1 9} \\
\text { Years }\end{array}$ & $\begin{array}{c}\mathbf{2 0 - 2 4} \\
\text { Years }\end{array}$ & $\begin{array}{c}\text { 25 Years } \\
\text { or over }\end{array}$ & Bachelor & Master & Doctor \\
\hline 21 & 9 & 4 & 15 & 8 & 3 & 5 & 14 & 5 & 6 & 4 & 14 & 12 \\
\hline
\end{tabular}


This first survey was conducted from February 12 to 28, 2018, by sending questionnaires to and requesting responses from the 30 experts; 27 of the questionnaires were returned. The respondents' opinions on 346 subfactors for cooperation under the four domains of Deutsch's cooperation theory were extracted. The subfactors were classified into 89 under communication, 84 under perception, 76 under attitudes toward each other, and 97 under work orientation.

Some subfactors were integrated into items, using the domain analysis by Spradley's technique. Based on the understanding of semantic contents (the same/similar), the subfactors were grouped under the representative words to derive 17 factors for cooperation (4-5 per domain of cooperation). To review each domain's details, factors for 'cooperation under communication' were derived as 'communication', 'information sharing', 'exchange activation', and 'knowledge sharing'. Factors under 'perception' were derived as 'goal sharing', 'responsibility awareness', 'vision sharing', and 'environmental analysis'. Factors under 'attitudes toward each other' were derived as 'mutual trust', 'mutual understanding', 'mutual dependence', and 'mutual binding'. Factors under work orientation were derived as role sharing, problem-solving, customer management, resource sharing, and outcome orientation (Table 5).

Table 5. Status of factors for cooperation derived under the four domains of cooperation.

\begin{tabular}{lccccrrrr}
\hline \multicolumn{2}{c}{ Communication (89) } & Perception (84) & & \multicolumn{2}{c}{$\begin{array}{c}\text { Attitudes toward Each Other } \\
\text { (76) }\end{array}$} & Work Orientation (97) \\
\hline Communication & 20 & Goal sharing & 19 & $\begin{array}{c}\text { Mutual } \\
\text { understanding }\end{array}$ & 20 & Problem-solving & 23 \\
\hline Information sharing & 23 & Responsibility awareness & 21 & Mutual trust & 18 & Problem-solving & 23 \\
\hline Exchange Activation & 25 & Vision sharing & 21 & Mutual Dependence & 18 & $\begin{array}{c}\text { Customer } \\
\text { Management }\end{array}$ \\
\hline Knowledge sharing & 21 & Environmental analysis & 23 & Mutual binding & 20 & Resource sharing & 17 \\
\hline
\end{tabular}

\subsection{Overview of the Second Expert Questionnaire Survey}

The second expert questionnaire survey was conducted by presenting 17 factors for cooperation under the four domains in Deutsch's cooperation theory and formulating questions about the factors for cooperation. This second survey was held from May 6 to 26, 2018, by distributing the questionnaires to 27 experts, and 25 questionnaires were collected. In total, 193 specific elements of cooperation were presented under the 17 factors for cooperation under the four domains, comprising 56 under 'communication', 47 under 'perception', 26 under 'attitudes toward each other', and 64 under 'work orientation' (Table 6).

\subsection{Identifying Factors for Cooperation between Convention Industry and Medical Tourism}

Spradley's 12-stage technique was modified into seven stages for a systematic and highly reliable analysis of the questionnaire survey results to identify factors for cooperation among the convention industry and medical tourism stakeholders.

\subsection{Domain and Taxonomic Analyses}

Based on the subfactors and individual elements of cooperation derived through the processes of the first and second questionnaire surveys, factors among the convention industry and medical tourism stakeholders were verified by domain and taxonomic analyses.

Domain analysis is to categorize the semantic relationships among cooperation factors. The domains of the extracted factors regarding cooperation were identified by using their relationships, such as the same/similar, attributes/the same dimension, and inclusion. Based on the results, general terms were derived, and their semantic relationships were figured out to find included terms. 


\subsection{Component Analysis, System Organization, and Content Preparation}

A component analysis found individual categories' attributes by classifying control points based on the outcomes of the domain and taxonomic analyses. The examined contents systematically categorized the factors for cooperation among the convention industry and medical tourism stakeholders into large, medium, and small classifications.

Table 6. Detailed elements under the four domains of cooperation.

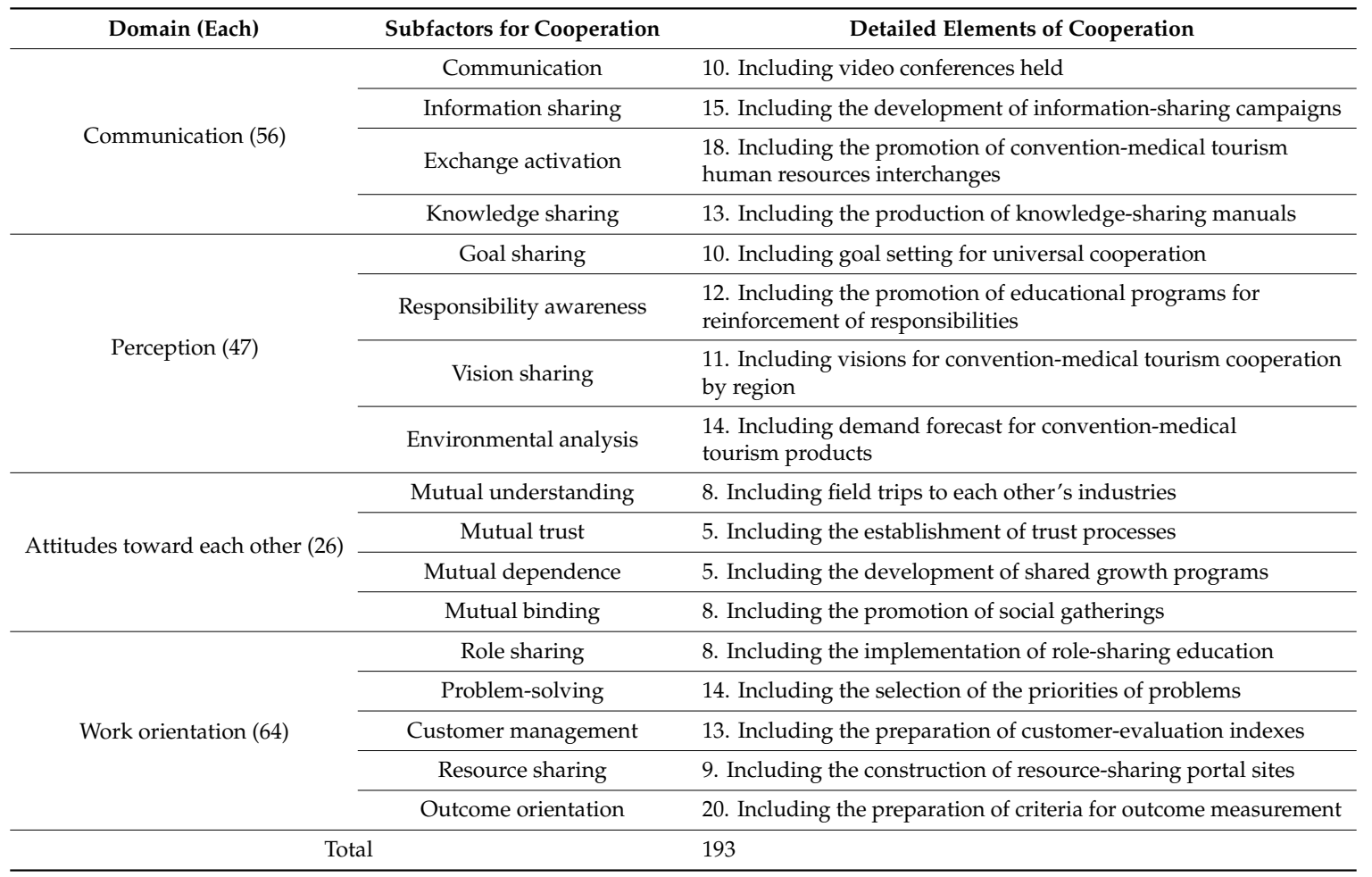

Under the 'communication' domain, the components of factors for cooperation between convention industry and medical tourism sectors divided into four under the broad classification (such as 'promoting online communication'), nine under the medium classification (including 'communication quickness'), and 27 under the small classification (including 'hold online conferences'). The details are shown in Table 7.

Under the 'perception' domain, the components of factors for cooperation between convention industry and medical tourism were divided into four under the broad classification (such as 'pursuit of cooperation goals'), ten under the medium classification (including 'inspiration for goal consciousness'), and 30 under the small classification (including 'share goal consciousness'). Table 8 presents the details.

Under the 'attitudes toward each other' domain, the components of factors for cooperation between convention industry and medical tourism sectors were divided into four under the broad classification (such as 'expansibility of mutual understanding'), six under the medium classification (including 'adequacy of mutual understanding'), and 18 under the small classification (including 'understand the culture and practice of each other's industry'). The details are shown in Table 9.

Under the 'work orientation' domain, the components of factors for cooperation between convention industry and medical tourism were divided into 5 under the large classification (such as 'establishment of cooperative work'), 14 under the medium classification (including 'concreteness of cooperative work'), and 42 under the small classification (including 'produce a cooperative work manual'). Table 10 presents the details. 
Table 7. Contents of detailed classification under the 'communication' domain of cooperation.

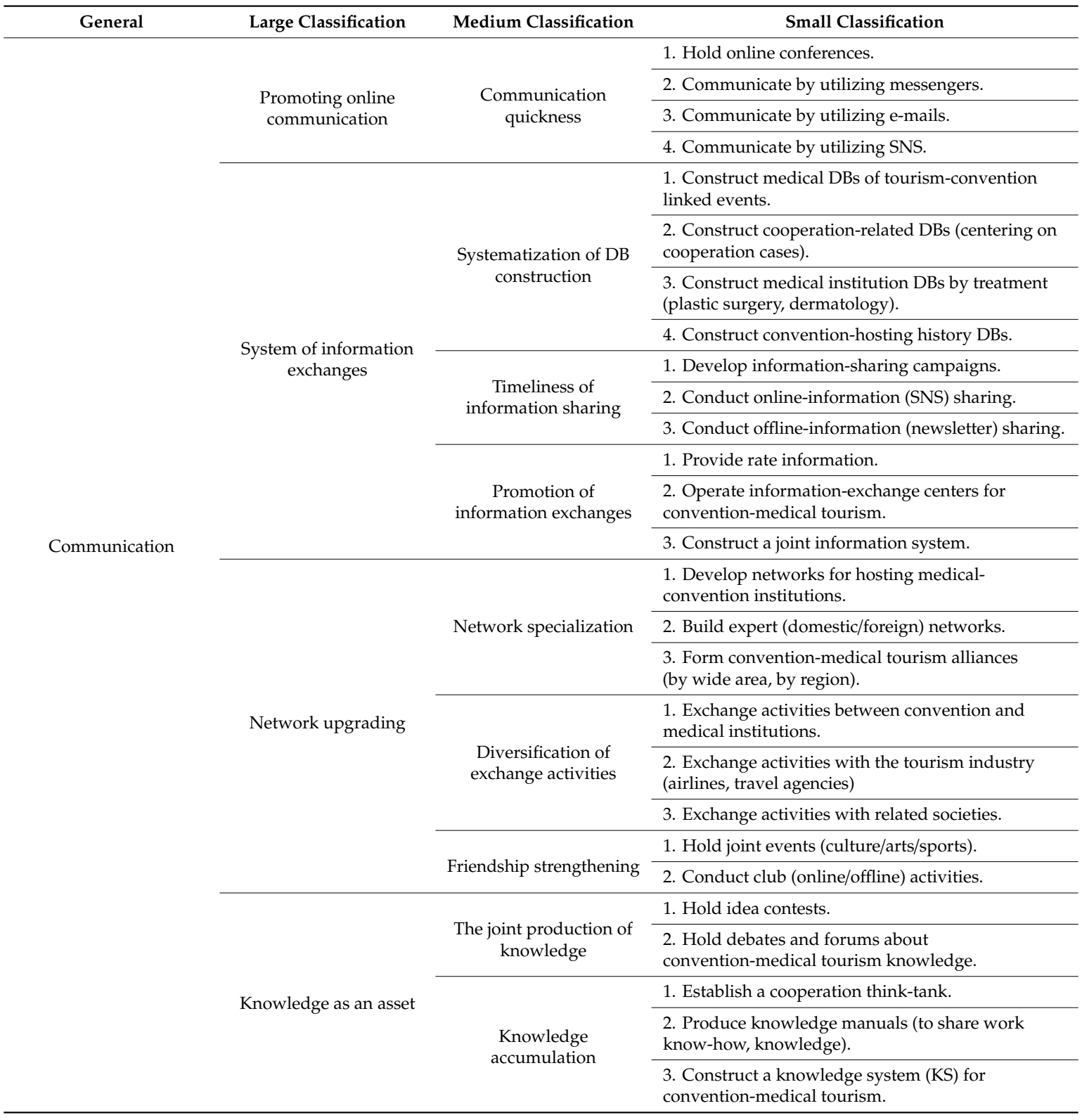

Table 8. Contents of detailed classification under the 'perception' domain of cooperation.

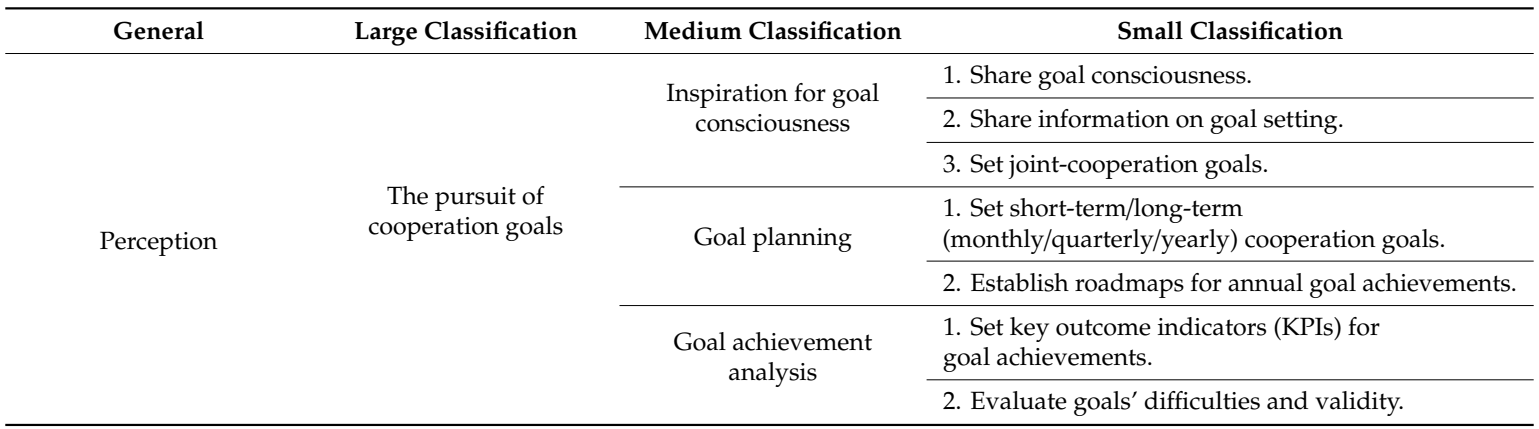


Table 8. Cont.

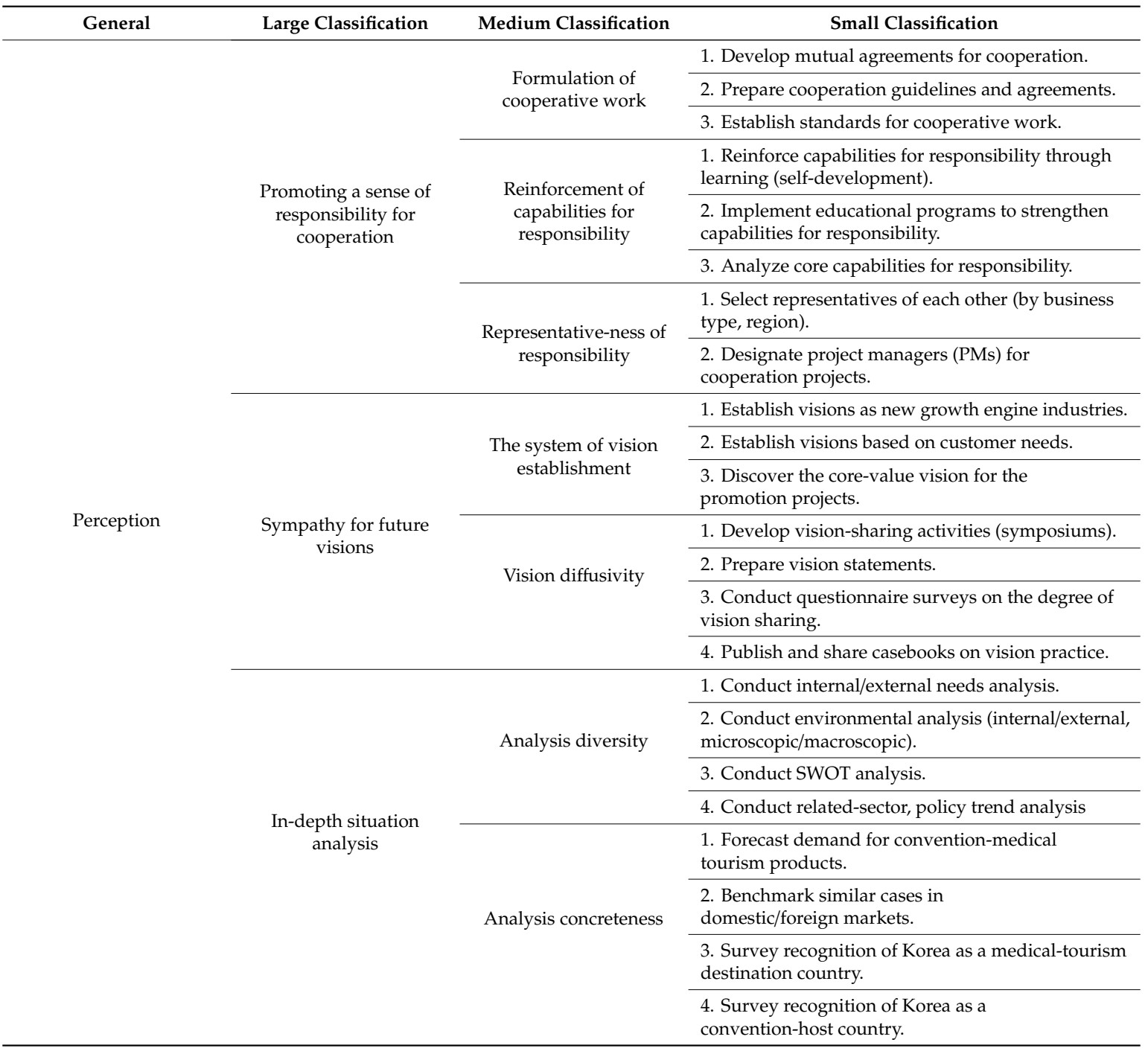

Table 9. Contents of detailed classification under the 'attitudes toward each other' domain of cooperation.

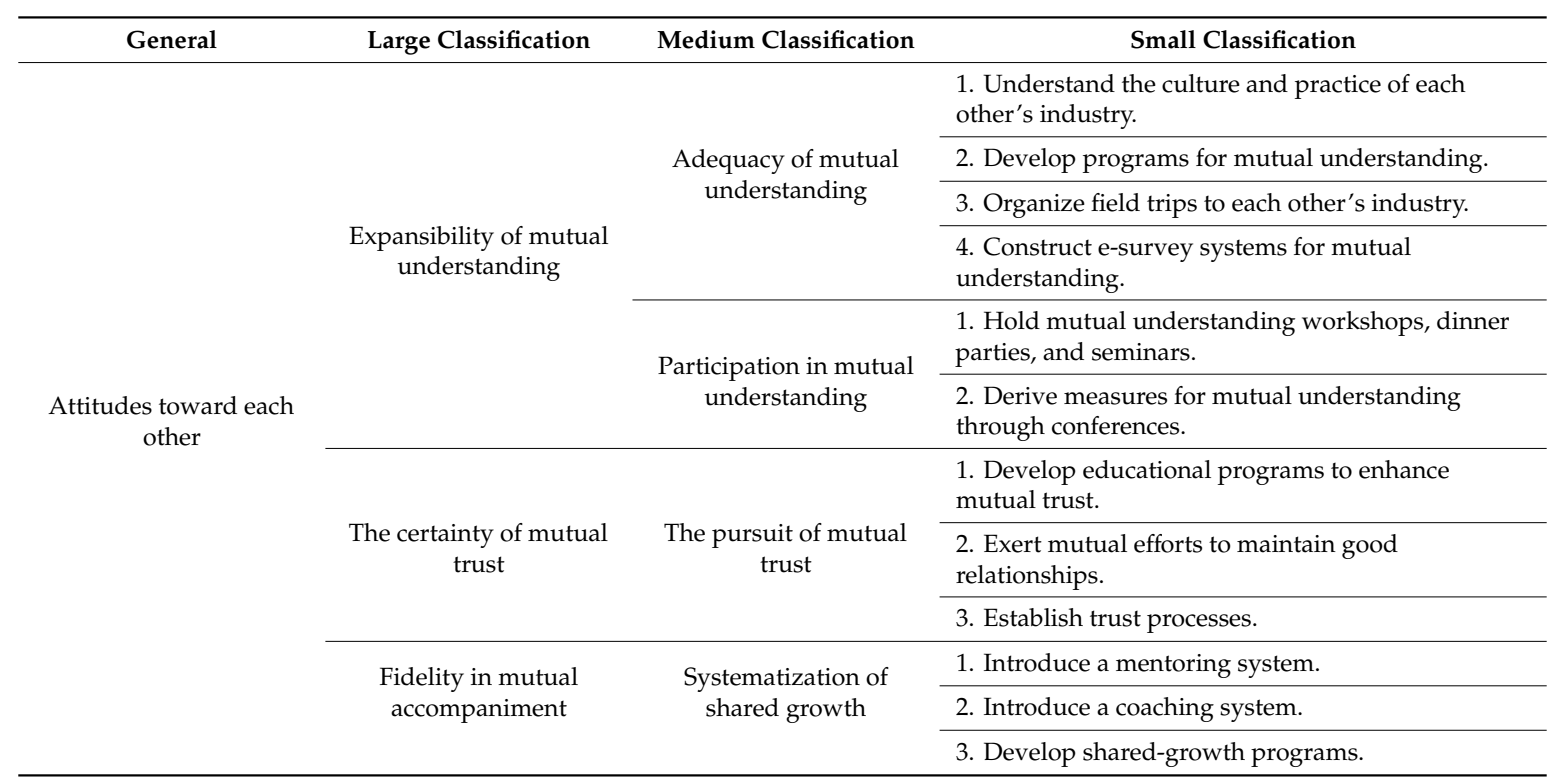


Table 9. Cont.

\begin{tabular}{|c|c|c|c|}
\hline General & Large Classification & Medium Classification & Small Classification \\
\hline \multirow{5}{*}{$\begin{array}{l}\text { Attitudes toward each } \\
\text { other }\end{array}$} & \multirow{5}{*}{$\begin{array}{l}\text { Mutually binding } \\
\text { orientation }\end{array}$} & \multirow{3}{*}{$\begin{array}{l}\text { Commitment to mutual } \\
\text { binding }\end{array}$} & $\begin{array}{l}\text { 1. Execute memorandums of understanding (MOU) } \\
\text { (local governments-medical institutions/convention } \\
\text { industry-medical institutions). }\end{array}$ \\
\hline & & & 2. Secure regional MICE alliance members. \\
\hline & & & $\begin{array}{l}\text { 3. Form a consultative group for the medical } \\
\text { tourism agency. }\end{array}$ \\
\hline & & \multirow[t]{2}{*}{$\begin{array}{l}\text { Bilateral friendship } \\
\text { exchanges }\end{array}$} & $\begin{array}{l}\text { 1. Hold friendship events (rallies to strengthen unity, } \\
\text { athletics meetings) }\end{array}$ \\
\hline & & & 2. Promote social meetings. \\
\hline
\end{tabular}

Table 10. Contents of detailed classification under the 'work orientation' domain of cooperation.

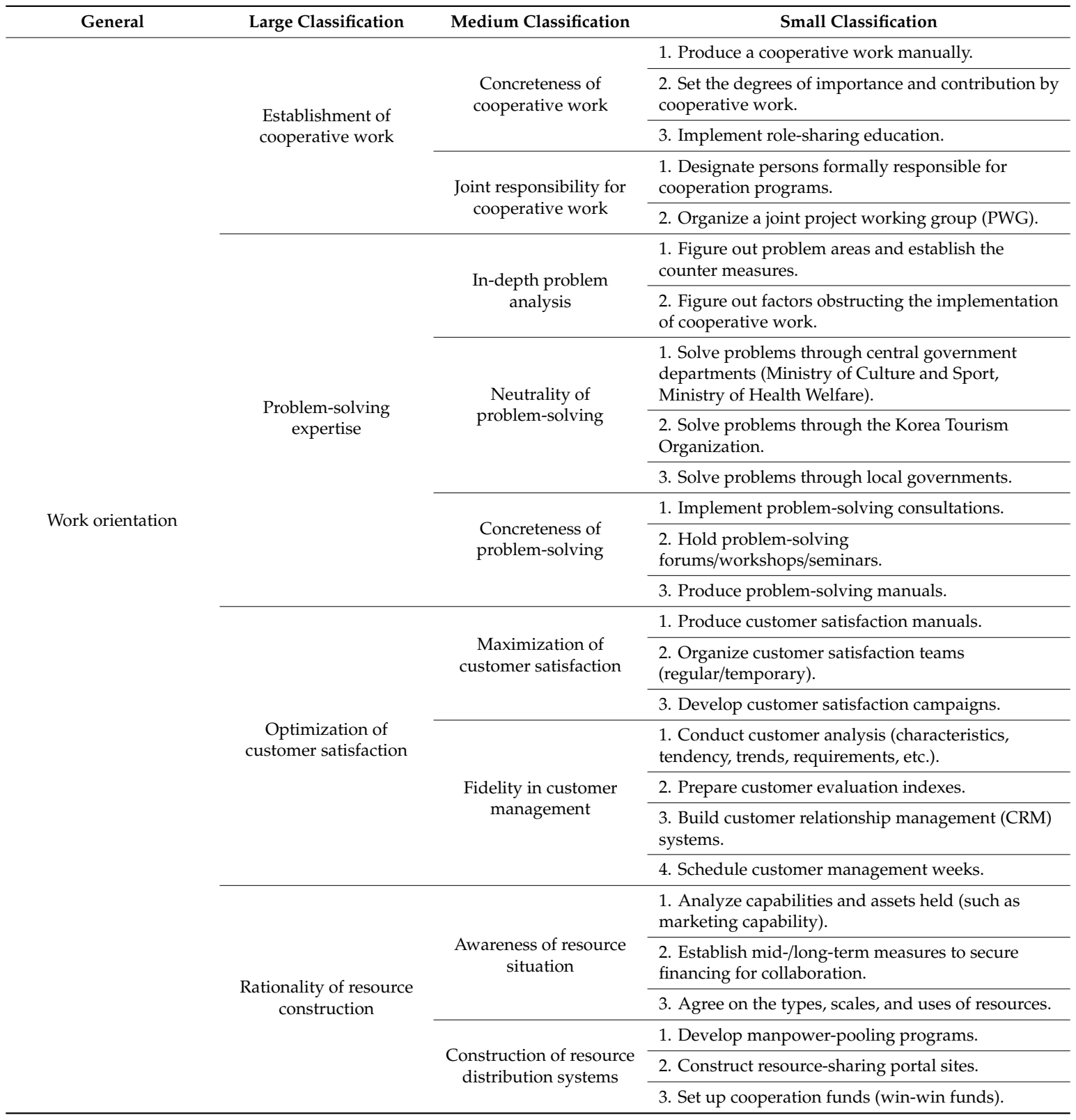


Table 10. Cont.

\begin{tabular}{|c|c|c|c|}
\hline General & Large Classification & Medium Classification & Small Classification \\
\hline \multirow{12}{*}{ Work orientation } & \multirow{12}{*}{$\begin{array}{l}\text { Maximization of the } \\
\text { outcome of cooperation }\end{array}$} & \multirow{2}{*}{$\begin{array}{l}\text { Adequacy of data } \\
\text { analysis }\end{array}$} & $\begin{array}{l}\text { 1. Calculate convention-medical tourism-related } \\
\text { statistics. }\end{array}$ \\
\hline & & & 3. Analyze cooperation projects $(\mathrm{I} / \mathrm{O}, \mathrm{B} / \mathrm{C})$. \\
\hline & & \multirow{2}{*}{ Cooperation branding } & $\begin{array}{l}\text { 1. Build convention-medical tourism } \\
\text { cooperation brands. }\end{array}$ \\
\hline & & & 3. Create convention-medical tourism slogans. \\
\hline & & \multirow{3}{*}{$\begin{array}{l}\text { Cooperation in } \\
\text { marketing optimization }\end{array}$} & 1. Construct public relations/marketing websites. \\
\hline & & & 2. Develop SNS public relations/marketing. \\
\hline & & & $\begin{array}{l}\text { 3. Enable joint participation in } \\
\text { exhibitions/expositions (domestic/overseas). }\end{array}$ \\
\hline & & $\begin{array}{l}\text { Outcome feedback } \\
\text { expertise }\end{array}$ & $\begin{array}{l}\text { 3. Conduct a satisfaction survey on } \\
\text { convention-medical tourism products. }\end{array}$ \\
\hline & & \multirow{4}{*}{$\begin{array}{l}\text { Diffusivity of feedback } \\
\text { on outcomes }\end{array}$} & $\begin{array}{l}\text { 1. Reinforce the linkage between cooperation } \\
\text { outcomes and compensation. }\end{array}$ \\
\hline & & & 2. Share cooperation outcome measurements. \\
\hline & & & 3. Discover and diffuse success cases in cooperation. \\
\hline & & & 4. Prepare cooperation certification systems. \\
\hline
\end{tabular}

A comprehensive comparison of the questionnaire survey results regarding the large-classification factors for cooperation and Spradley's qualitative study is shown in Table 11.

Table 11. A comprehensive comparison of the large-classification factors for cooperation under the domains of cooperation.

\begin{tabular}{|c|c|c|}
\hline \multirow{2}{*}{ Domains of Cooperation } & \multicolumn{2}{|c|}{ Large-Classification Factors for Cooperation } \\
\hline & Results of Expert Questionnaire Surveys & Results of Spradley's Qualitative Study \\
\hline \multirow{4}{*}{ Communication } & Communication & Promoting online communication \\
\hline & Information sharing & System of information exchanges \\
\hline & Exchange activation & Network upgrading \\
\hline & Knowledge sharing & Knowledge as an asset \\
\hline \multirow{4}{*}{ Perception } & Goal sharing & The pursuit of cooperation goals \\
\hline & Responsibility awareness & Promoting a sense of responsibility for cooperation \\
\hline & Vision sharing & Sympathy for future visions \\
\hline & Environmental analysis & Situation analysis deepening \\
\hline \multirow{4}{*}{ Attitudes toward each other } & Mutual understanding & Expansibility of mutual understanding \\
\hline & Mutual trust & The certainty of mutual trust \\
\hline & Mutual dependence & Fidelity in mutual accompaniment \\
\hline & Mutual binding & Mutually binding orientation \\
\hline \multirow{5}{*}{ Work orientation } & Role sharing & Establishment of cooperative work \\
\hline & Problem-solving & Problem-solving expertise \\
\hline & Customer management & Optimization of customer satisfaction \\
\hline & Resource sharing & Rationality of resource construction \\
\hline & Outcome orientation & Maximization of the outcome of cooperation \\
\hline
\end{tabular}

\subsection{Reliability Analysis}

The derived factors for cooperation among the convention industry and medical tourism stakeholders were verified by conducting simple consistency reviews and participant, peer, and expert reviews. The reliability measurement (simple consistency), which was conducted by comparing 
the factors for cooperation derived from the first and second questionnaire surveys, was shown to be at acceptable levels, with the average value exceeding $87 \%$ (Table 12).

Table 12. Results of reliability measurements.

\begin{tabular}{cccc}
\hline Division & Large Classification (17) & Medium Classification (39) & Small Classification (117) \\
\hline Number of consistent items & 15 & 33 & 104 \\
\hline Number of inconsistent items & 2 & 6 & 13 \\
\hline Degree of consistency & $88 \%$ & $85 \%$ & $89 \%$ \\
\hline
\end{tabular}

\section{Development of a Cooperative Convention-Medical Tourism Model}

\subsection{The Conceptual Framework for the Convention-Medical Tourism Cooperation Model}

The conceptual framework of Chen's [35] program logic theory was applied to develop a cooperation model for convention-medical tourism (Figure 1). First, the construction of a cooperation system among the convention industry and medical tourism stakeholders was regarded as a program. Next, the essential resources and environments that affect the implementation the program involving the implementing organizations and implementers were considered. A causal logic between implementing the convention-medical tourism cooperation program considered the mutual relationship between an action model under prescriptive assumptions and a change model under descriptive assumptions (as discussed in the next section).

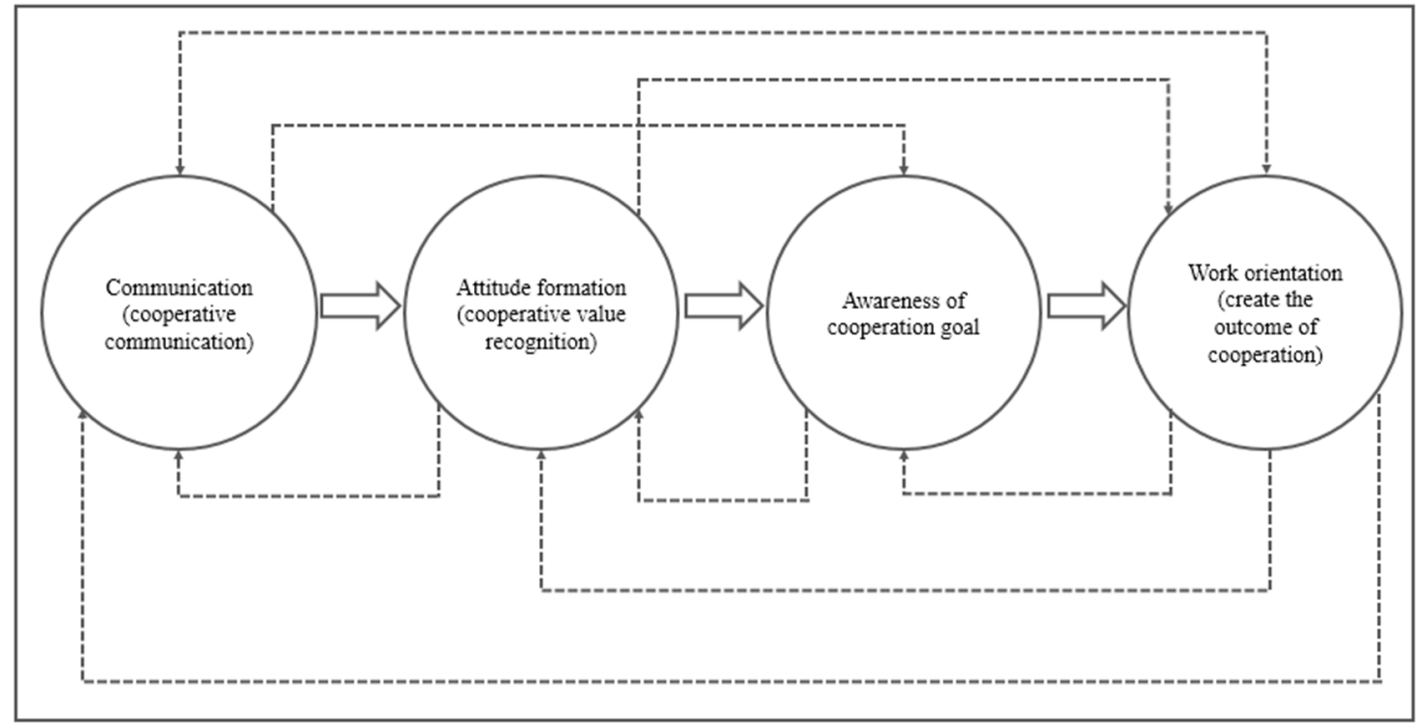

Figure 1. Establishment of causal relationships among the domains of convention-medical tourism cooperation.

\subsection{Establishing Causal Relationships between the Domains of Convention-Medical Tourism Cooperation}

Since prescriptive assumptions are preconditions for implementing and reinforcing cooperation programs, the activation of 'communication' with each other, and the formation of trusting and depending attitudes are necessary. These affect the 'perception' of the necessity and effectiveness of cooperation among the convention industry and medical tourism stakeholders as a descriptive assumption and create the intended outcomes. From the viewpoint of the action model, communication, and the formation of attitudes toward each other are implementing. From the viewpoint of the change model, the construction of cooperation systems under goal setting, and the creation of outcomes have causal relationships with each other as a virtuous cycle (Figure 2). 


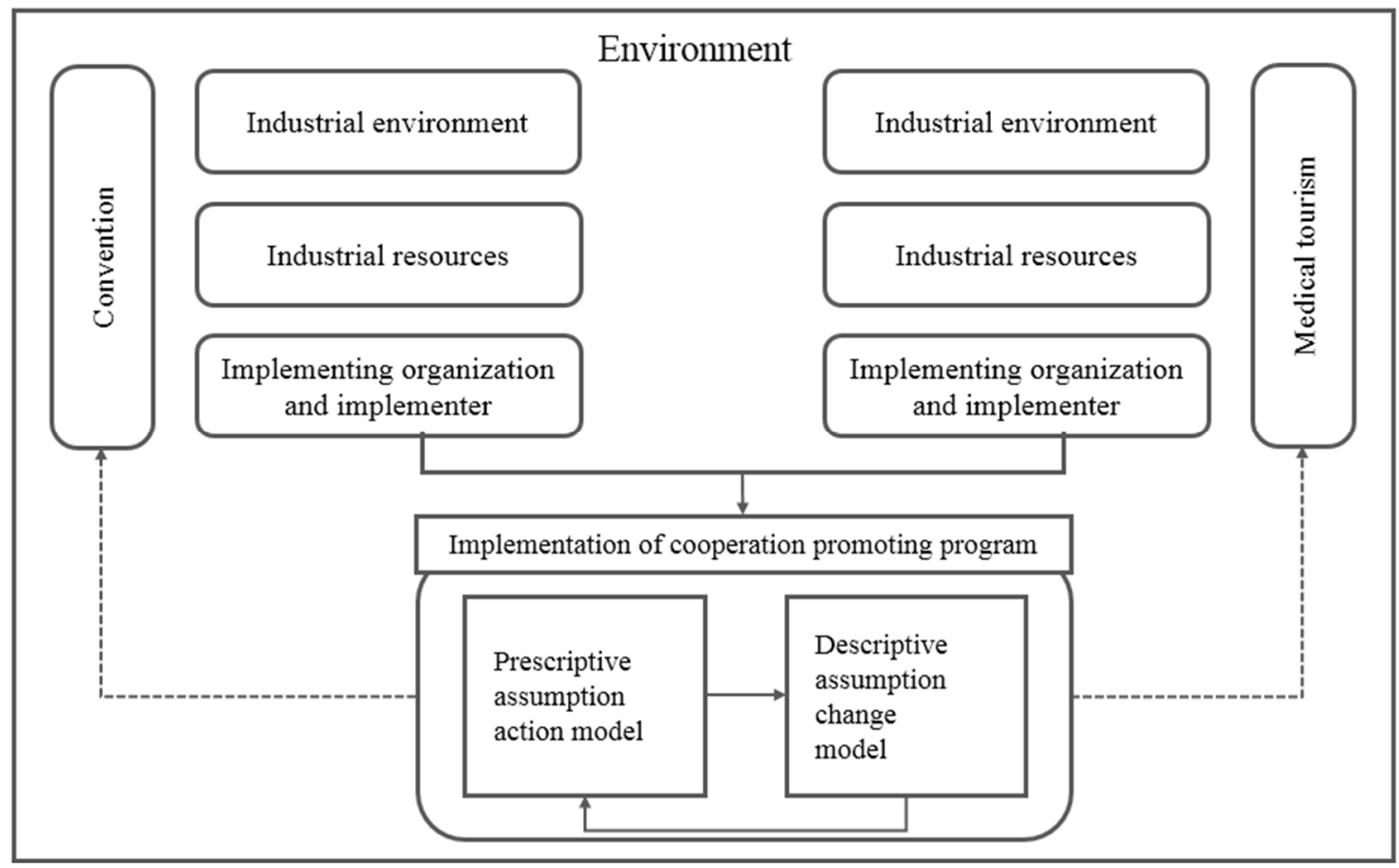

Figure 2. Conceptual frame for the development of a convention-medical tourism cooperation model.

\subsection{Development of Convention-Medical Tourism Cooperation Model}

This study developed a cooperative model, focusing on four domains regarding conventionmedical tourism cooperation. This model includes the analysis of the relationships between large- and medium-classification factors by domains. The group discussions with six experts in the convention industry and medical tourism sectors accomplished these processes. The developed convention-medical tourism cooperation model was named the "CON-MED cooperation model".

\subsection{Communication: A CON-MED Information-Knowledge Connectivity Model}

A domain process to acquire cooperation knowledge as an asset formed the network upgrading and systematization of information exchanges, based on the promotion of online communication through the setting of the relationships between the four large- and nine medium-classification factors for cooperation under the 'communication' domain. This process was called the "CON-MED information-knowledge connectivity" domain model.

\subsection{Attitude: A CON-MED Cooperation Value Recognition Model}

A domain process to achieve a mutually binding orientation was derived through fidelity in mutual accompaniment, based on the expansibility of mutual understanding and the certainty of mutual trust through the setting of the relationships between the four large- and six medium-classification factors for cooperation under the 'attitudes toward each other' domain. This process was named the "CON-MED cooperation value recognition" domain model.

\subsection{Perception: A CON-MED Cooperation System Model}

A domain process to attain situation analysis concretization, future vision system diffusion, reinforcement and formulation of responsibility for cooperation, and cooperation goal setting was derived through the setting of the relationships between the four large- and ten medium-classification factors for cooperation under the 'perception' domain. This process was labeled the "CON-MED cooperation system" domain model. 


\subsection{Work Orientation: A CON-MED Cooperation Outcome Model}

A domain process realized the establishment of cooperative work, the optimization of customer satisfaction, and the maximization of the outcome of cooperation. Those factors derive from the problem-solving expertise and the rationality of resource construction derived the setting of the relationships between the five large- and 14 medium-classification factors for cooperation under the 'work orientation' domain. This process was named the "CON-MED cooperation outcome" domain model.

\subsection{Development of an Integrated CON-MED Cooperation Model}

A CON-MED cooperation model was derived from integrating the domain models, as mentioned above. The model expresses the setting of the causal relationships among convention-medical tourism cooperation domains, as shown in Figure 3.

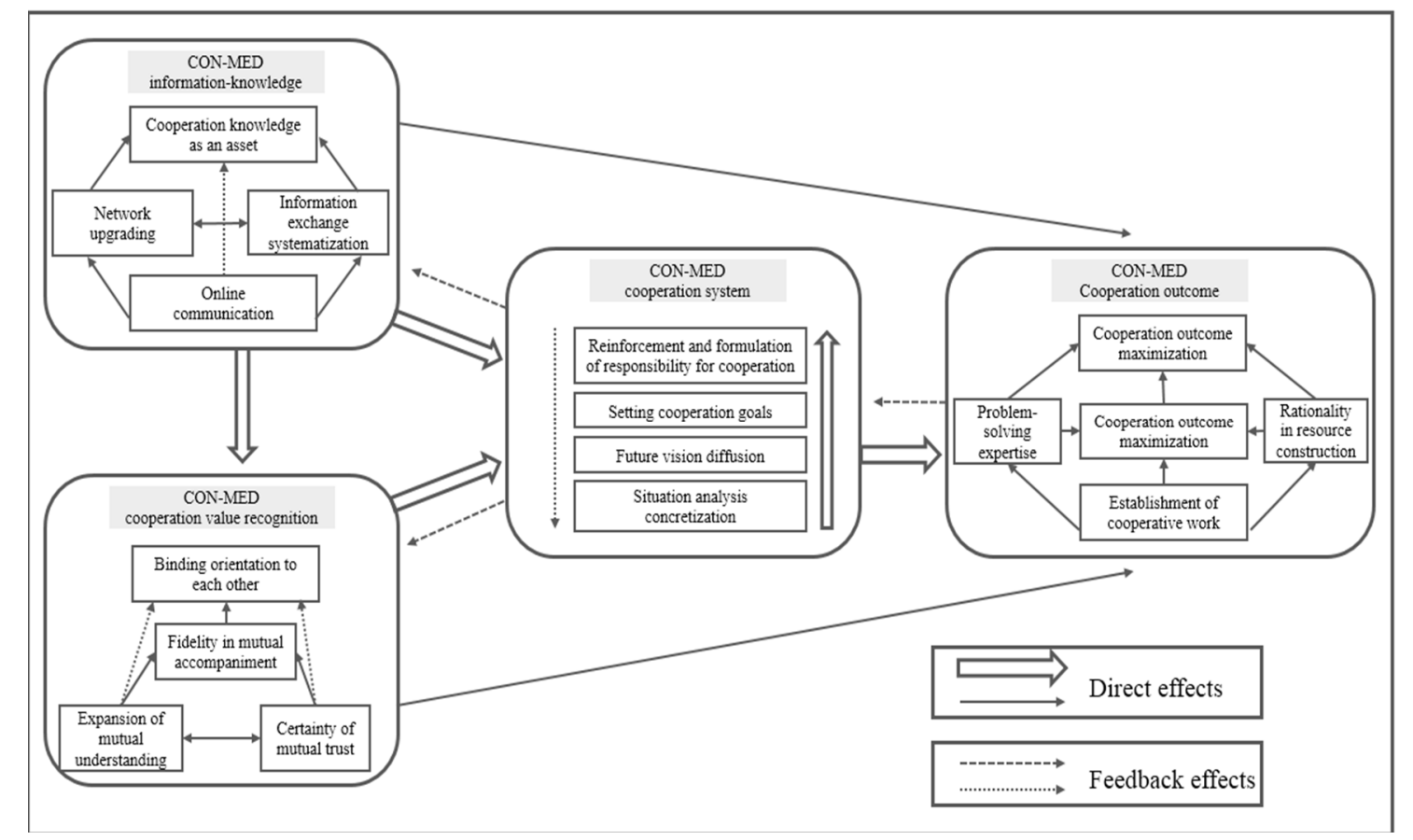

Figure 3. CON-MED (convention-medical tourism) cooperation model.

\section{Conclusions}

The twofold purpose of this study was to derive the factors for cooperation among the convention industry and medical tourism stakeholders and to develop an integrated cooperation model. Modified Spradley's analysis technique was used and identified 193 specific factors regarding cooperation among the convention industry and medical tourism stakeholders. The results indicated that the factors for cooperation among the convention industry and medical tourism stakeholders could comprise of 17 large-, 39 medium-, and 117 small-classification items under four domains. A cooperation model was identified.

This study has the following significant outcomes. It can be claimed as academically significant since (to our best knowledge) it was the first to examine the relationships among convention industry and medical tourism stakeholders. This study derived the factors for cooperation and developed a realistic cooperation model. In contrast, previous studies on the relationships among convention stakeholders are scarce. Scientific studies on medical tourism have been recently increasing in volume. However, the studies are limited to certain areas, such as selection attributes and product development. Previous studies on medical tourism stakeholders are also extremely insufficient, and studies on cooperation among the convention industry and medical tourism stakeholders do not exist. 
This study made practical implications in terms of developing both industries. The study implied a direction for cooperation among the convention industry and medical tourism stakeholders and the evaluation of cooperation and joint projects for future-oriented development of the two sectors. Also, in line with the stream of tourism 4.0 age, which creates synergy effects through convergence among different industries, the integrated cooperation model would significantly contribute to collaboration or convergence among various stakeholders. Both the medical and health tourism markets have high susceptibility to innovation [36]. This is due to the functioning of not only convention firms on the tourism market, but above all the providers of medical services. Convergence of both convention and medical tourism sectors should contribute to achieving sustainability through innovation of two markets characterized by high-development dynamics.

This study has several limitations and suggestions for future study. Since previous studies on cooperation among the convention industry and medical tourism stakeholders were in a vacuum, this study can argue the results' generalizability and transferability. Namely, although (to our best knowledge) this study was the first to present a cooperation model among convention industry and medical tourism stakeholders from an integrated viewpoint, it was not possible to reflect all the diversity of the two industries' environments. The model should be examined by a large-scale sampling survey to get reliability and validity.

Moreover, although the study derived factors and models for convention-medical tourism cooperation through integrated approaches, further research should also apply to various detailed areas, such as planning, marketing, and human resources operation.

Future studies must verify cooperation models at more detailed levels. Finally, although the synergy effects obtained through the two sectors' collaboration can be predictable later, the cooperation between them is still unclear. If such collaboration implements systematically, follow-up studies with high degrees of completion in deriving additional cooperation areas and their factors can be expected.

Author Contributions: Conceptualization, Literature Review, and Analysis, D.A.; Conceptualization and Investigation, J.H., Supervision and project management, C.K.; Writing-original draft, D.A.; Writing-review \& edition, C.K. and J.H. All authors have read and agreed to the published version of the manuscript.

Funding: This research received no external funding.

Conflicts of Interest: The authors declare no conflict of interest.

\section{References}

1. Bramwell, B.; Lane, B. Tourism Collaboration and Partnerships: Politics, Practice, and Sustainability; Bramwell, B., Lane, B., Eds.; Channel View Publications: Bristol, UK, 2000.

2. Jamal, B.T.; Getz, D. Collaboration theory and community tourism planning. Ann. Tour. Res. 1995, 22, $186-204$. [CrossRef]

3. Vernon, J.; Essex, S.; Pinder, D.; Curry, K. Collaborative policymaking: Local sustainable projects. Ann. Tour. Res. 2005, 32, 325-345. [CrossRef]

4. Dredge, D.; Gyimóthy, S. The collaborative economy and tourism: Critical perspectives, questionable claims, and silenced voices. Tour. Recreat. Res. 2015, 40, 286-302.

5. Bornhorst, T.; Ritchie, B.; Sheehan, L. Determinants of tourism success for DMOs \& destinations: An empirical examination of stakeholders' perspectives. Tour. Manag. 2010, 31, 572-589.

6. Douglas, A.; Lubbe, B.A. Identifying value conflicts between stakeholders in corporate travel management by applying the soft value management model: A survey in South Africa. Tour. Manag. 2006, 27, 1130-1140. [CrossRef]

7. Ford, R.C.; Peeper, W.C.; Gresock, A. Friends to grow and foes to know: Using a stakeholder matrix to identify management strategies for convention and visitors bureaus. J. Conv. Event Tour. 2009, 10, 166-184. [CrossRef]

8. Wang, Y.; Fesenmaier, D.R. Collaborative destination marketing: A case study of Elkhart county, Indiana. Tour. Manag. 2007, 28, 863-875. [CrossRef] 
9. Brochado, A.; Troilo, M.; Shah, A. Airbnb customer experience: Evidence of convergence across three countries. Ann. Tour. Res. 2017, 63, 210-212. [CrossRef]

10. Martínez, P.; Pérez, A.; Del Bosque, I.R. Exploring the role of CSR in the organizational identity of hospitality companies: A case from the Spanish tourism industry. J. Bus. Ethics 2014, 124, 47-66. [CrossRef]

11. Hudson, S. Working together to leverage film tourism: Collaboration between the film and tourism industries. Worldw. Hosp. Tour. Themes 2011, 3, 165-172. [CrossRef]

12. Weaver, D.B. Organic, incremental and induced paths to sustainable mass tourism convergence. Tour. Manag. 2012, 33, 1030-1037. [CrossRef]

13. Gretzel, U.; Koo, C.; Sigala, M.; Xiang, Z. Special issue on smart tourism: Convergence of information technologies, experiences, and theories. Electron. Mark. 2015, 25, 175-177. [CrossRef]

14. Sigala, M. Collaborative commerce in tourism: Implications for research and industry. Curr. Issues Tour. 2017, 20, 346-355. [CrossRef]

15. Reddy, S.G.; York, V.K.; Brannon, L.A. Travel for treatment: students' perspective on medical tourism. Int. J. Tour. Res. 2010, 12, 510-522. [CrossRef]

16. Han, H.; Kim, Y.; Kim, C.; Ham, S. Medical hotels in the growing healthcare business industry: Impact of international travelers' perceived outcomes. J. Bus. Res. 2015, 68, 1869-1877. [CrossRef]

17. Van Niekerk, M. Contemporary issues in events, festivals, and destination management. Int. J. Contemp. Hosp. Manag. 2017, 29, 842-847. [CrossRef]

18. Sayili, M.; Akca, H.; Duman, T.; Esengun, K. Psoriasis treatment via doctor fishes as part of health tourism: A case study of Kangal Fish Spring, Turkey. Tour. Manag. 2007, 28, 625-629. [CrossRef]

19. Wernz, C.; Thakur Wernz, P.; Phusavat, K. Service convergence and service integration in medical tourism. Ind. Manag. Data Syst. 2014, 114, 1094-1106. [CrossRef]

20. Freeman, R.E.; Reed, D.R. Stockholders and stakeholders: A new perspective on corporate governance. Calif. Manag. Rev. 1983, 25, 65-88. [CrossRef]

21. Freeman, R.E. Strategic Management: A Stakeholder Approach; Pitman: Boston, MA, USA, 1984.

22. Gray, B. Conditions facilitating international collaboration. Hum. Relat. 1985, 38, 911-936. [CrossRef]

23. Bryson, J.M.; Crosby, B.C. Leadership for the Common Good: Tackling Public Problems in a Shared-Power World; Jossey-Bass: San Francisco, CA, USA, 1992.

24. Davis, K.; Frederick, W.C. Business and Society: Corporate Strategy, Policy, Ethics; McGraw-Hill International Editions: New York, NY, USA, 1984.

25. Ryan, C. Equity, management, power-sharing and sustainability issues of the new tourism. Tour. Manag. 2002, 23, 17-26. [CrossRef]

26. Panfiluk, E.; Panasiuk, A.; Szymańska, E. Identification of the flow of innovations in tourism related the aesthetic medicine. Int. J. Manag. Econ. 2017, 53, 107-119. [CrossRef]

27. Deutsch, M. Resolution of Conflict: Constructive and Destructive Processes; Yale University Press: New Haven, CT, USA, 1973.

28. Edwards, W. The theory of decision making. Psychol. Bull. 1954, 51, 380. [CrossRef]

29. Lewin, K.; Dembo, T.; Festinger, L.; Sears, P.S. Level of aspiration. In Personality and the Behavior Disorders; Hunt, J.M., Ed.; Ronald Press: New York, USA, 1944; pp. 333-378.

30. Deutsch, M. A theory of cooperation and competition. Hum. Relat. 1949, 2, 129-152. [CrossRef]

31. Deutsch, M. Distributive Justice: A Social-Psychological Perspective; Yale University Press: New Haven, CT, USA, 1985.

32. Tjosvold, D. Cooperative and competitive interdependence collaboration between departments to serve customers. Group Organ. Manag. 1988, 13, 274-289.

33. Lim, S.G.S.; Murnighan, J.K. Phases, deadlines, and the bargaining process. Organ. Behav. Hum. Decis. Process. 1994, 58, 153-171. [CrossRef]

34. Spradley, J.P. Participant Observation; Holt: New York, NY, USA, 1980.

35. Chen, H.T. A conceptual framework of program theory for practitioners. Pract. Program Eval. 2005, 15, 42.

36. Panasiuk, A. Theoretical aspects of innovation in health tourism. Eur. J. Serv. Manag. 2018, 25. [CrossRef] 